\title{
Analisis Komparasi Karakter, Kapasitas dan Modal Peternak Terhadap Tingkat Kelancaran Mengulirkan Ternak Pola Gaduhan Ternak Sapi Pemerintah
}

\section{Comparative Analysis of Character, Capacity and Capital of Farmers Against the Smoothness of Turning Cattle on the Local Government's Beef Cattle Patterns}

\author{
Radhiati Rahmi', Afriani Harahap ${ }^{2}$, dan Firmansyah ${ }^{2}$ \\ ${ }^{1}$ Alumni Fakultas Peternakan Universitas Jambi \\ Email : radhiatirahmi@gmail.com \\ ${ }^{2}$ Dosen Fakultas Peternakan Universitas Jambi
}

\begin{abstract}
Diterima $\quad: 28$ Juli 2021
Disetujui $\quad: 17$ Agustus 2021

Diterbitkan : 31 Agustus 2021
\end{abstract}

\begin{abstract}
Abstrak: Penelitian bertujuan untuk mengetahui perbedaan karakter, kapasitas dan modal yang dimiliki peternak dan tingkat kelancaran dalam mengembalikan ternak sapi antara pola gaduhan ternak sapi pemerintah daerah antara Kabupaten Tebo dengan Merangin. Penelitian ini dilakukan pada 2 Kabupaten di Provinsi Jambi yaitu Kabupaten Merangin dan Tebo. Adapun metode penelitian adalah metode survei dengan teknik penarikan sampel adalah Stratified Random Sampling yaitu : Strata I adalah pola gulir anak, dan Strata II adalah pola gulir induk, serta Strata III adalah model yang lain. Untuk mengetahui perbedaan menggunakan uji beda. Terdapat perbedaan karakter peternak dan modal yang dimiliki peternak pada pola gaduhan ternak sapi pemerintah daerah antara Kabupaten Tebo dengan Merangin, sedangkan pada kategori kapasitas peternak di Kabupaten Tebo dan Kabupaten Merangin dapat dikatakan sama. Tingkat kelancaran pengguliran ternak pada pola gaduhan ternak sapi di Kabupaten Tebo lebih baik dibandingkan dengan Kabupaten Merangin.
\end{abstract}

Kata Kunci: kelancaran, perguliran, ternak sapi

Abstract: The study aims to determine differences in character, capacity and capital owned by farmers and the level of fluency in returning cattle between local government rowdy cattle patterns between Tebo Regency and Merangin. This research was conducted in 2 districts in Jambi Province, namely Merangin and Tebo Regencies. The research method is a survey method with the sampling technique is Stratified Random Sampling namely: Strata I is a child scroll pattern, and Strata II is the parent scroll pattern, and Strata III is another model. To find out the difference using the different test. There is a difference in the character of the breeders and the capital owned by the breeders in the noise pattern of local government cattle breeding between Tebo Regency and Merangin, while in the category of breeders' capacities in Tebo Regency and Merangin Regency it can be said to be the same. The smooth rate of cattle rolling in the noise pattern of cattle in Tebo Regency is better than Merangin Regency.

Keywords: hunger, turning, cattle

\section{Pendahuluan}

Keberhasilan kebijakan penyebaran dan pengembangan ternak sapi Pemerintah Daerah di Kabupaten Tebo dan Kabupaten Merangin belum berjalan sesuai dengan harapan, misalnya penggaduh/peternak belum maksimal menyetorkan induk atau anak sapi kepada Pemerintah Daerah baik dari segi jumlah, waktu dan kualitas, hal tersebut disebabkan banyak faktor. Hasil penelitian [1] menemukan banyak peternak baru mulai beternak sapi pada saat mendapat bantuan sapi pemerintah daerah baik pada pola gulir induk maupun gulir anak sapi. Menurut penelitian [2], petani-peternak yang mendapat bantuan ternak sapi dalam program bantuan pemerintah sebagian besar gagal karena salah satu faktornya ternak mati dan sebagian petani menjual ternaknya.

Pemilihan calon peternak penerima bantuan ternak pada pola gaduhan ternak sapi pemerintah daerah Kabupaten Tebo dan Kabupaten Merangin harus benar-benar sesuai dengan kriteria yang telah ditetapkan, terutama calon peternak yang memiliki 
pengalaman beternak, serta karakter yang baik, jujur, dan memiliki kemampuan dalam mengelolah usaha. Hasil penelitian [3] menunjukkan bahwa identifikasi dan seleksi calon peternak (Calon Penggaduh) berpengaruh signifikan terhadap produktivitas bibit sapi pokok dan revolving anak sapi pada program pengembangan usaha peternakan sapi pola gaduhan sistem revolving. Kebijakan penyebaran dan pengembangan ternak sapi bergulir harus menerapkan prinsip kehati-hatian dan analisis calon peternak dan calon lokasi melalui modifikasi dan rekayasa model perbankan dengan model karakter, kapasitas dan modal. Berdasarkan kepada uraian di atas, dalam rangka memberikan solusi masalah rendahnya keberhasilan program pola gaduhan ternak sapi pemerintah daerah di Kabupaten Tebo dan Kabupaten Merangin maka dilakukan penelitian tentang Analisis Komparasi Karakter, Kapasitas dan Modal Peternak Terhadap Tingkat Kelancaran Mengulirkan Ternak pada Pola Gaduhan Ternak Sapi Pemerintah.

\section{Metode Penelitian}

Penelitian ini dilakukan pada 2 Kabupaten di Provinsi Jambi yang mendapat program bantuan ternak sapi pemerintah daerah Provinsi Jambi yaitu Kabupaten Merangin dan Tebo.

\subsection{Metode Pengumpulan Data}

Adapun metode penelitian yang digunakan pada penelitian ini adalah metode survei, yaitu pemeriksaan atau penelitian secara komprehensif. Survei yang dilakukan dalam penelitian biasanya dilakukan dengan menyebarkan kuesioner atau wawancara, dengan tujuan untuk mengetahui: siapa responden, bagaimana keadaaan responden, atau kecenderungan suatu tindakan [4].

\subsection{Metode Sampling}

Penelitian menggunakan metode sampling dengan teknik penarikan sampel yang digunakan pada penelitian ini adalah Stratified Random Sampling [5] dalam sampling acak stratifikasi, populasi dibagi menjadi dua segmen atau lebih yang mutually exclusive yang disebut strata/stratum yang terdiri dari 3 (tiga) strata yaitu : strata I adalah peternak yang mendapat bantuan ternak sapi dengan pola gulir anak, dan strata II adalah peternak yang mendapat bantuan ternak sapi dengan pola gulir induk, serta strata III adalah peternak yang mendapat bantuan ternak sapi dengan model yang lain. Variabel yang relevan dari satu atau lebih, baru kemudian dilakukan Simple Random Sampling. Strata merupakan kumpulan dari stratum-stratum, anggota dalam stratum diusahakan sehomogen mungkin, sedangkan antar stratum ada perbedaan. Sehingga dalam sampling acak stratifikasi setiap stratum terwakili dalam sampel artinya pengambilan sampel dilakukan terhadap semua stratum dengan menggunakan prosedur sampling acak sederhana.

Setelah ditentukan populasi sasaran beserta strata populasi, maka ditentukan ukuran sampel n yang disebut overall sample size. Penentuan ukuran sampel pada penelitian ini, menggunakan rumus ukuran sampel minimum sebagai berikut:

$$
n=\frac{N}{N d^{2}+1}
$$

Keterangan :

$$
\begin{array}{ll}
\mathrm{n} & =\text { Ukuran sampel } \\
\mathrm{N} & =\text { Ukuran populasi } \\
\mathrm{d} & =\text { Presisi yang diinginkan }
\end{array}
$$

$$
\begin{gathered}
\text { Kabupaten Tebo : } \mathrm{n}=\frac{235}{235(0,1)^{2}+1}=\frac{235}{2,35+1}=\frac{235}{3,35} \\
=70,14(70 \text { peternak })
\end{gathered}
$$

Selanjutnya, setelah menentukan ukuran sampel keseluruhan n, maka langkah selanjutnya adalah mengalokasikan atau menyebarkan satuan-satuan sampling ke dalam strata. Penelitian ini menggunakan proportional allocation dengan rumus:

$$
n_{i}=\frac{N_{i}}{N} \times n
$$

Keterangan :

$$
\begin{array}{ll}
\mathrm{n} & =\text { Ukuran sampel } \\
\mathrm{n}_{\mathrm{i}} & =\text { Ukuran sampel untuk stratum ke } \mathrm{i} \\
\mathrm{N} & =\text { Ukuran populasi } \\
\mathrm{N}_{\mathrm{i}} & =\text { Ukuran populasi untuk stratum ke } \mathrm{i}
\end{array}
$$

Jumlah sampel (peternak) yang digunakan pada penelitian ini berjumlah 135 orang peternak. Kabupaten Tebo berjumlah 70 orang (Gulir anak : 48 orang, Gulir Induk : 11 orang, Gulir Lainnya : 11 orang) dan pada Kabupaten Merangin berjumlah 65 orang peternak (Gulir anak : 32 orang, Gulir Induk : 23 orang, Gulir Lainnya : 10 orang).

\subsection{Analisis Data}

\subsubsection{Uji validitas dan reliabilitas instrumen penelitian}

Validitas adalah suatu ukuran yang menunjukkan tingkat keaslian suatu alat ukur (instrumen) [6]. Uji validitas alat ukur kuesioner menggunakan rumus Korelasi Product Moment Pearson berdasarkan [7] sebagai berikut:

$$
r_{\mathrm{x} \gamma}=\frac{n \sum X Y-\left(\sum X\right)\left(\sum X\right)}{\sqrt{\left\{n \sum X^{2}-\left(\sum X\right)^{2}\right\}\left\{n \sum Y^{2}-\left(\sum Y\right)^{2}\right.}}
$$

Keterangan :

$\mathrm{r}_{\mathrm{xy}} \quad=$ Koefisien validitas $\mathrm{xy}$

$x=$ Skor masing- masing variabel 
$\mathrm{Y} \quad=$ Variabel (ekonomi dan non ekonomi)

$\mathrm{n} \quad=$ Jumlah pertanyaan

Bila hitung $\mathrm{r}_{\mathrm{xy}}>\mathrm{r}_{\text {tabel }}(\mathrm{n}=2 ; 5 \%)$ maka hasil pengukuran valid.

Reliabilitas adalah derajat ketepatan, ketelitian atau keakuratan yang ditunjukkan oleh instrumen pengukuran. Untuk mengetahui koefisien reliabilitas instrumen (Cronbach) dapat menggunakan rumus sebagai berikut:

$$
r 11=\left[\frac{k}{k-1}\left[1-\frac{\sum \sigma h^{2}}{\sigma 1^{2}}\right]\right]
$$

$\mathrm{r}_{11}=$ reliabilitas instrument, $\mathrm{k}=$ banyak butir pertanyaan, 21 = varian total, $21=$ jumlah varian butir, 1 = konstanta. Santoso dan Ashari (2005) dalam [8] menyatakan bahwa suatu kuesioner dikatakan reliabel jika nilai Cronbach Alpha lebih besar dari o,6o sehingga kuesioner layak digunakan dalam penelitian.

\subsubsection{Tranformasi data melalui method of succesive interval (MSI)}

Skala pengukuran dari data yang diperoleh adalah bervariasi yaitu nominal, skala ordinal dan rasio. Untuk data yang mempunyai skala ordinal dengan menggunakan skala Likert, atau pengukuran sikap. Salah satu metode konversi data yang sering digunakan oleh peneliti untuk menaikan tingkat pengukuran ordinal ke interval adalah metode succesive interval.

\subsubsection{Analisis kelancaran, kepatuhan dan kerelaan peternak pada pola gaduhan}

Untuk menganalisis bagaimana tingkat kelancaran peternak dalam mengembalikan atau mengulirkan ternak sapi, kepatuhan peternak dalam mengganti ternak sapi yang mati/hilang dan kerelaan peternak dalam menanggung resiko sesuai perjanjian pada pola gaduhan ternak sapi pemerintah daerah antara Kabupaten Tebo dengan Merangin dapat digunakan analisis seperti pada Tabel $\mathbf{1}$.

Tabel 1. Tingkat kelancaran peternak dalam mengembalikan atau mengulirkan ternak sapi

\begin{tabular}{clccc}
\hline No & Kategori & $\begin{array}{c}\text { Pengembalian anak umur 1 } \\
\text { Tahun (Ekor) }\end{array}$ & Waktu (Tahun) & Skor \\
\hline 1. & Lancar & 2 & 5 & 3 \\
2. & Kurang lancar & 1 & 5 & 2 \\
3. & Tidak lancar & 0 & 5 & 1 \\
\hline
\end{tabular}

\subsubsection{Uji Beda}

Untuk mengetahui perbedaan karakter, kapasitas, modal yang dimiliki, tingkat kelancaran, kepatuhan, keleraaan peternak pada pola gaduhan ternak sapi pemerintah daerah antara Kabupaten Merangin dengan Kabupaten Tebo menggunakan Uji $\mathrm{t}$ dengan rumus :

$t-$ hitung $=\frac{\overline{X_{1}}-\overline{X_{2}}}{\sqrt{\frac{S_{1}^{2}}{n_{1}}+\frac{S_{2}^{2}}{n_{2}}}}$

Keterangan :

$\overline{X_{1}}=$ Rata-rata karakter, kapasitas, modal yang dimiliki, tingkat kelancaran, kepatuhan, keleraaan peternak pada pola gaduhan ternak sapi pemerintah daerah Kabupaten Tebo

$\overline{X_{2}}=$ Rata-rata karakter, kapasitas, modal yang dimiliki, tingkat kelancaran, kepatuhan, keleraaan peternak pada pola gaduhan ternak sapi pemerintah daerah Kabupaten Merangin

$S_{1}^{2}=$ Varians karakter, kapasitas, modal yang dimiliki, tingkat kelancaran, kepatuhan, keleraaan peternak pada pola gaduhan ternak sapi pemerintah daerah Kabupaten Tebo

$S_{2}^{2}=$ Varians karakter, kapasitas, modal yang dimiliki, tingkat kelancaran, kepatuhan, keleraaan peternak pada pola gaduhan ternak sapi pemerintah daerah Kabupaten Merangin

$n_{1}=$ Jumlah sampel peternak pola gaduhan ternak sapi pemerintah daerah Kabupaten Tebo

$n_{2} \quad=$ Jumlah sampel peternak pola gaduhan ternak sapi pemerintah daerah Kabupaten Merangin

\section{Hasil dan Pembahasan}

\subsection{Karakter peternak}

Karakteristik individu adalah sifat-sifat atau ciri yang melekat pada diri individu yang berhubungan dengan aspek kehidupan di lingkungannya. Karakter merupakan faktor penting dalam pemberian bantua, karena menyangkut kepribadian terutama menyangkut kejujuran dari calon penggaduh. Karakteristik akan berpengaruh terhadap tingkat adopsi inovasi. Untuk melihat karakter seorang peternak dapat dilihat dari kelancaran pembayaran listrik, PBB, koperasi, simpan pinjam dan kredit motor.

Karakter seorang peternak sebelum mendapat bantuan dapat dilihat dari kelancaran pembayaran tagihan listrik, PBB, Koperasi, simpan pinjam dan kredit motor sebagai pertimbangan dalam memberi bantuan (Tabel 2). Kelancaran pembayaran listrik di 
Kabupaten Tebo lebih banyak membayar listriknya dengan tepat waktu yaitu sebanyak 57 orang $(44,29$ \%) dibandingkan dengan Kabupaten Merangin 28 orang $(43,08 \%)$. Hal ini dikarenakan mayoritas masyarakat di Kabupaten Merangin lebih banyak menggunakan Token yaitu berjumlah 37 orang $(56,92$ $\%)$, dan sebagian kecil menggunakan listrik amper yang pembayarannya selalu tepat waktu yaitu sebanyak 28 orang $(43,08 \%)$.

Kelancaran pembayaran PBB di Kabupaten Tebo dapat dikatakan sempurna yaitu lancar 70 orang (100 $\%)$, hal ini dikarenakan peraturan setempat yang langsung melakukan pemotong gaji untuk pembayaran $\mathrm{PBB}$ sehingga tidak ada peternak yang menunggak pembayaran PBB. Berbeda halnya dengan Kabupaten Merangin masih ada 5 orang $(7,69$ $\%)$ yang pembayaran PBBnya sekali-kali terlambat.
Keikutsertaan peternak dalam sebuah koperasi di Kabupaten Tebo lebih banyak dibandingkan dengan Kabupaten Merangin. Peternak di Kabupaten Tebo memiliki kelancaran yang cukup baik dalam pembayaran koperasinya yaitu sebanyak 38 orang (54,29 \%) dibandingkan Kabupaten Merangin yang hanya 5 orang $(7,69 \%)$. Dilihat dari kegiatan simpan pinjam Kabupaten Tebo lebih baik dibandingkan Kabupaten Merangin, pada Kabupaten Tebo sebagian besar peternak tidak ikut serta dalam simpan pinjam. Dari segi lain kelancaran pembayaran kredit motor di Kabupaten Tebo lebih baik 35,71\% dibandingkan Kabupaten Merangin yaitu 24,62 \%. Hal ini dapat dikatakan bahwa peternak di Kabupaten Tebo memiliki kemampuan lebih terhadap perekonominya dibandingkan dengan Kabupaten Merangin.

Tabel 2. Karakter peternak

\begin{tabular}{|c|c|c|c|c|c|c|}
\hline \multirow{2}{*}{ No } & \multirow{2}{*}{ Karakter } & \multirow{2}{*}{ Kategori } & \multicolumn{2}{|c|}{ Tebo } & \multicolumn{2}{|c|}{ Merangin } \\
\hline & & & Jumlah & $\%$ & Jumlah & $\%$ \\
\hline \multirow{3}{*}{1} & \multirow{3}{*}{ Listrik } & 1.Token & 9 & 37,14 & 37 & 56,92 \\
\hline & & 2. Kurang tepat & 4 & 18,57 & o & 0,00 \\
\hline & & 3. Tepat & 57 & 44,29 & 28 & 43,08 \\
\hline \multirow{3}{*}{2} & \multirow{3}{*}{ PBB } & 1. Tidak bayar & o & o,oo & o & 0,00 \\
\hline & & 2. Sekali-kali terlambat & o & 0,00 & 5 & 7,69 \\
\hline & & 3. Tepat Waktu & 70 & 100,00 & 60 & 92,31 \\
\hline \multirow{3}{*}{3} & \multirow{3}{*}{ Koperasi } & 1. Tidak ikut koperasi & 32 & 45,71 & 60 & 92,31 \\
\hline & & 2. Kurang tepat bayar & o & o,oo & o & o,oo \\
\hline & & 3. Tepat waktu bayar & 38 & 54,29 & 5 & 7,69 \\
\hline \multirow{3}{*}{4} & \multirow{3}{*}{$\begin{array}{l}\text { Simpan } \\
\text { Pinjam }\end{array}$} & 1. Tidak ikut & 69 & 98,57 & 55 & 84,62 \\
\hline & & 2. Sekali-kali terlambat & o & 0,00 & 1 & 1,54 \\
\hline & & 3. Tepat waktu bayar & 1 & 1,43 & 9 & 13,85 \\
\hline \multirow{3}{*}{5} & \multirow{3}{*}{$\begin{array}{l}\text { Kredit } \\
\text { Motor }\end{array}$} & 1. Tidak ada & 39 & 55,71 & 39 & 60,00 \\
\hline & & 2. Sekali-kali terlambat & 5 & 7,14 & 10 & 15,38 \\
\hline & & 3. Tepat waktu bayar & 26 & 37,14 & 16 & 24,62 \\
\hline
\end{tabular}

\subsection{Kapasitas Peternak}

\subsubsection{Sistem pemeliharaan}

Sistem pemeliharaan ternak sapi di Kabupaten Tebo dan Kabupaten Merangin (Tabel 3) memiliki sistem pemeliharaan yang sama yaitu tradisional dan semi intensif. Sistem pemeliharaan ternak sapi yang dominan dipakai oleh peternak Kabupaten Tebo dan Kabupaten Merangin yaitu semi intensif, dimana pemeliharaan sapi dilakukan di padang penggembalaan pada siang hari dan dikandangkan pada sore hari. Padang penggembalaan merupakan sumber penyediaan hijauan yang lebih ekonomis dan murah. Padang penggembalaan tersebut bisa terdiri dari rumput seluruhnya atau leguminose saja, ataupun campuran.

Sistem pemeliharaan eksternal dan intensif juga dipakai oleh peternak tetapi itu hanya sebagian kecil, di Kabupaten Tebo total peternak yang melakukan pemeliharaan secara ekstensif hanya sebesar 18,57 \% dan Kabupaten Merangin sebesar 9,23\%, begitupun pada system pemeliharaan intensif Kabupaten Tebo hanya berjumlah 7,14 \% dan Kabupaten Merangin berjumlah 7,69\%. Hal ini dikarenakan peternak yang memilih beternak eksternal tidak memiliki tenaga untuk mencari pakan sendiri. Lain halnya dengan peternak yang memilih sistem pemeliharaan intensif karena peternak ini lebih mengutamakan kesehatan ternaknya sehingga mereka menyediakan tenaga untuk mencari pakan hijauan dan konsentrat yang berkualitas agar ternak berkembang dengan baik. Sistem pemeliharaan sapi potong dikategorikan dalam tiga cara yaitu sistem pemeliharaan intensif yaitu ternak dikandangkan, sistem pemeliharaan semi intensif yaitu ternak dikandangkan pada malam hari dan dilepas di ladang penggembalaan pada pagi 
hari dan sistem pemeliharaan ekstensif yaitu ternak dilepas di padang penggembalaan.

\subsubsection{Pakan yang diberikan}

Pakan yang diberikan oleh peternak penerima bantuan ternak pada pola gaduhan ternak sapi di Kabupaten Tebo dan Kabupaten Merangin mayoritas memberikan pakan hijauan dan memberi hijauan dengan campuran konsentrat. Pakan hijauan diperoleh peternak dari kebunnya sendiri atau lingkungan sekitar kandang. Adapun jenis rumput yang diberikan yaitu, rumput gajah, rumput ilalang, leguminosa dan rumputan liar lainnya. Sedangkan jenis konsentrat yang biasa diberikan yaitu berupa ampas tahu. Konsentrat digunakan peternak sebagai pakan tambahan untuk ternak sapinya, tetapi hanya sebagian kecil peternak yang menggunakan konsentrat. Hal ini dikarenakan keterbatasan biaya untuk pembelian konsentrat, sehingga peternak yang tidak mampu hanya bisa memberikan pakan hijaun saja. Untuk penentu keberhasilan pengembangan ternak sapi yaitu ketersediaan hijauan yang cukup jumlah maupun kualitas dan berkesinambungan [2].

Tabel 3. Sistem pemeliharaan ternak sapi di Kabupaten Tebo dan Kabupaten Merangin

\begin{tabular}{|c|c|c|c|c|c|c|}
\hline \multirow{2}{*}{ No } & \multirow{2}{*}{ Kategori } & \multirow{2}{*}{ Pemeliharaan } & \multicolumn{2}{|c|}{ Tebo } & \multicolumn{2}{|c|}{ Merangin } \\
\hline & & & Jumlah & $\%$ & Jumlah & $\%$ \\
\hline \multirow{3}{*}{1} & \multirow{3}{*}{ Gulir Anak } & Ekstensif & 11 & 23,40 & o & 0,00 \\
\hline & & Semi Intensif & 34 & 72,34 & 28 & 88,24 \\
\hline & & Intensif & 2 & 4,26 & 4 & 11,76 \\
\hline \multirow{3}{*}{2} & \multirow{3}{*}{ Gulir Induk } & Ekstensif & 1 & 8,33 & 5 & 19,23 \\
\hline & & Semi Intensif & 10 & 83,33 & 17 & 76,92 \\
\hline & & Intensif & 1 & 8,83 & 1 & 3,85 \\
\hline \multirow{3}{*}{3} & \multirow{3}{*}{ Gulir Lainnya } & Ekstensif & 1 & 9,09 & 1 & 20,00 \\
\hline & & Semi Intensif & 8 & 72,73 & 9 & 80,00 \\
\hline & & Intensif & 2 & 18,18 & $\mathrm{O}$ & 0,00 \\
\hline \multirow{3}{*}{\multicolumn{2}{|c|}{ Total }} & Ekstensif & 13 & 18,57 & 6 & 9,23 \\
\hline & & Semi Intensif & 52 & 74,29 & 54 & 83,08 \\
\hline & & Intensif & 5 & 7,14 & 5 & 7,69 \\
\hline
\end{tabular}

\subsubsection{Modal yang dimiliki peternak}

Modal merupakan hal pertama yang dibutuhkan saat seseorang memulai usaha, begitu juga dalam menjalankan usaha peternakan. Modal dapat berasal dari berbagai sumber seperti dana pribadi, dana pinjaman maupun bantuan sosial dari lembaga-lembaga tertentu. Modal yang dimiliki peternak (Tabel 4) dapat dilihat dari beberapa aspek yaitu jumlah ternak yang dimiliki, biaya pembelian pakan konsentrat, biaya pembuatan kandang yang di keluarkan, serta biaya yang dikeluarkan untuk pembelian perlengkapan alatalat kandang seperti cangkul, sikat, sapu dan pakan konsentrat yang diberikan.

Tabel 4. Modal peternak

\begin{tabular}{llrr}
\hline \multirow{2}{*}{ No } & Kategori & \multicolumn{2}{c}{ Rata-rata Modal } \\
\cline { 3 - 4 } 1 & Bibit sapi & Tebo (Rp) & Merangin (Rp) \\
2 & Biaya pembuatn kandang & 14.642 .857 & 20.630 .769 \\
3 & Cangkul & 1.115 .714 & 1.349 .231 \\
4 & Sikat & 38.286 & 51.232 \\
5 & Sapu & 71 & 1.108 \\
6 & Pakan konsentrat & 2.529 & 5.123 \\
\hline & Total rata-rata & 386 & 677 \\
\hline
\end{tabular}

Dari hasil penelitian (Tabel 4 ) modal rata-rata yang dimiliki peternak penggaduh di Kabupaten Tebo lebih besar dibandingkan dengan Kabupaten Merangin. Bahwa modal yang dimiliki penggaduh di Kabupaten Tebo yaitu Rp12.114.050,oo sedangkan di Kabupaten Merangin Rp11.421.306,oo. Hal ini dikarenakan di Kabupaten Tebo memiliki ternak sebelum mendapat bantuan sehingga modal untuk 
penyediaan kandang dan pakan lebih besar, sedangkan di Kabupaten Merangin sebagian besar peternak baru mulai memelihara ternak sewaktu mendapat bantuan.

\subsection{Kelancaran Pengguliran Ternak}

Sistem perguliran yang digunakan pada pola gaduhan ternak sapi di Kabupaten Tebo dan Kabupaten Merangin yaitu setiap peternak yang menerima bantuan ternak sapi dari pemerintah wajib untuk menggulirkan ternak yang mereka terima kepada penggaduh berikutnya. Prosedurnya yaitu apabila seorang peternak menerima satu ekor sapi dewasa maka peternak tersebut harus menggulirkan sapi itu kembali setelah memiliki dua ekor anak yang anak keduanya sudah lepas sapih kepada peternak yang lain dalam kurun waktu yang telah disepakati. Kelancaran mengembalikan ternak pola gaduhan ternak sapi Kabupaten Tebo dan Kabupaten Merangin dapat dilihat pada Tabel 5.

Tabel 5. Total kelancaran peternak menggulirkan ternak pada pola gaduhan ternak sapi Kabupaten Tebo dan Kabupaten Merangin

\begin{tabular}{llcccc}
\hline \multirow{2}{*}{ Ko } & Kategori & \multicolumn{2}{c}{ Tebo } & \multicolumn{2}{c}{ Merangin } \\
\cline { 3 - 5 } & & Jumlah & $\%$ & Jumlah & $\%$ \\
\hline 1 & Lancar & 37 & 52.86 & 26 & 40,00 \\
2 & Kurang lancar & 32 & $45 \cdot 71$ & 16 & 24,62 \\
3 & Tidak lancar & 1 & 1.43 & 23 & 35,38 \\
\hline
\end{tabular}

Kelancaran mengembalikan ternak pola gaduhan ternak sapi Kabupaten Tebo lebih lancar dengan persentase 52,86\% (37 orang) dibandingkan Kabupaten Merangin yang hanya 40,00 \% (26 orang). Hal ini disebabkan karena peternak yang mendapat bantuan di Kabupaten Merangin merupakan orang-orang yang tidak memiliki pengalaman beternak. Sehingga pada saat mendapatkan ternak meraka tidak mengetahui cara-cara yang benar dalam pemeliharaan ternak sapi dan pada akhirnya sebagian ternak mati. Hal ini sesuai dengan pendapat [9] bahwa berdasarkan pengalaman tersebut maka anggota peternak umumnya masih belum memahami tatalaksana pemeliharaan yang benar, seperti halnya aspek pemberian pakan yang belum memperhatikan terhadap kuantitas dan kualitas pakan yang memenuhi syarat hidup dan produksi ternak, penanganan pada masa pra sapih dan berproduksi, pengelolaan kandang yang bersih, maupun pengelolaan limbah kandang.

Kelancaran perguliran ternak akan menentukan berhasil atau tidaknya program bantuan yang diberikan, baik oleh pihak pemerintah maupun pihak swasta. Tujuan dari pemberian bantuan ternak adalah untuk meningkatkan kesejahteraan peternak. Tujuan dari program bantuan ternak sapi yang dilakukan oleh pemerintah adalah untuk meningkatkan jumlah populasi ternak melalui optimalisasi sumber daya yang dimiliki, perbaikan manajemen, serta bantuan terkait yang diberikan kepada peternak yang membentuk kelompok tani.

\subsubsection{Gulir Anak}

Kelancaran perguliran pada sistem gulir anak di Kabupaten Merangin lebih lancar 81,25 \% (26 orang) dibandingkan Kabupaten Tebo yang hanya 52,08 \% (25 orang). Hal ini dikarenakan pada saat penelitian dilakukan penggaduh belum mengembalikan anak sapi disebabkan belum lepas sapih, sehingga belum dilakukan pengguliran. Perbandingan kelancaran pengguliran pada gulir anak antara Kabupaten Tebo dan Kabupaten Merangin Dapat dilihat pada Tabel 6.

Tabel 6. Kelancaran pengguliran pada sistem gulir anak

\begin{tabular}{|c|c|c|c|c|c|}
\hline \multirow{2}{*}{ No } & \multirow{2}{*}{ Kategori } & \multicolumn{2}{|c|}{ Tebo } & \multicolumn{2}{|c|}{ Merangin } \\
\hline & & Jumlah & $\%$ & Jumlah & $\%$ \\
\hline 1 & Lancar & 25 & 52,08 & 26 & 81,25 \\
\hline 2 & Kurang lancar & 22 & 45,83 & 6 & 18,75 \\
\hline 3 & Tidak lancar & 1 & 2,08 & $\mathrm{o}$ & 0,00 \\
\hline
\end{tabular}

\subsubsection{Gulir induk}

Perbedaan yang sangat jelas antara Kabupaten Tebo dan Kabupaten Merangin, pada Kabupaten Tebo mayoritas peternak yang mendapatkan bantuan ternak sapi sudah melakukan perguliran kategori lancar sebesar 63,64 \% (7 orang) berbeda dengan Kabupaten Merangin yang belum satupun yang melakukan perguliran. Peternak di Kabupaten Merangin dominan belum melakukan perguliran sama sekali yaitu 91,30 \% (21 orang). Penyebab kurang lancarnya perguliran ternak bantuan 
pemerintah karena ada sebagian peternak yang belum sampai pada waktu perguliran sedangkan penyebab tidak lancarnya perguliran ternak karena ada sebagian ternak yang mati dan dijual oleh peternak. Perbandingan kelancaran pengguliran pada gulir induk antara Kabupaten Tebo dan Kabupaten Merangin dapat dilihat pada Tabel 7.

Tabel 7. Kelancaran pengguliran pada sistem gulir induk

\begin{tabular}{llcccc}
\hline \multirow{2}{*}{ No } & \multirow{2}{*}{ Kategori } & \multicolumn{3}{c}{ Tebo } & \multicolumn{3}{c}{ Merangin } \\
\cline { 2 - 6 } & & Jumah & $\%$ & Jumlah & $\%$ \\
\hline 1 & Lancar & 7 & 63,64 & 0 & 0,00 \\
2 & Kurang lancar & 4 & 36,36 & 2 & 8,70 \\
3 & Tidak lancar & 0 & 0,00 & 21 & 91,30 \\
\hline
\end{tabular}

\subsubsection{Gulir lainnya}

Kelancaran peternak dalam mengembalikan ternak pada kategori gulir lainnya masih sangat rendah, dapat dilihat di Kabupaten Tebo peternak / penggaduh yang berada pada kategori kurang lancar lebih banyak dibandingkan dengan kategori lancar. Pada Kabupaten Tebo pengembalian ternak yang kurang lancar berjumlah 6 orang (54,55 \%), sedangkan pada kategori lancar hanya 5 orang.
Begitupun pada Kabupaten Merangin kategori kurang lancar berjumlah lebih banyak yaitu 8 orang (8o,oo \%) sedangkan pada kategori lancar beluam ada satupun. Hal tersebut dapat disimpulkan bahwa Kabupaten Tebo lebih baik dibandingkan dengan Kabupaten Merangin. Perbandingan kelancaran pengguliran pada gulir lainnya antara Kabupaten Tebo dan Kabupaten Merangin Dapat dilihat pada Tabel 8.

Tabel 8. Kelancaran pengguliran pada sistem gulir lainnya

\begin{tabular}{llcccc}
\hline \multirow{2}{*}{ No } & Kategori & \multicolumn{2}{c}{ Tebo } & Jumlah & $\%$ \\
\cline { 3 - 6 } & & Jumlah & $\%$ & 0 & o,oo \\
\hline 1 & Lancar & 5 & 45,45 & 8 & 8 o, oo \\
2 & Kurang lancar & 6 & 54,55 & 2 & 20, oo \\
3 & Tidak lancar & 0 & o,oo & \\
\hline
\end{tabular}

\subsection{Komparasi Kelancaran Pengguliran, Karakter, Kapasitas, dan Modal Peternak antara Kabupaten Tebo dan Merangin}

\subsubsection{Kelancaran pengguliran ternak}

Perbedaan tingkat kelancaran pengguliran ternak pada pola gaduhan ternak sapi antara Kabupaten Tebo dan Kabupaten Merangin dapat dilihat pada Tabel 9. Berikut ini nilai sig. (2-tailed) sebesar 0,001 < 0,05, maka dapat disimpulkan bahwa terdapat perbedaan tingkat kelancaran perguliran ternak pada pola gaduhan ternak sapi antara Kabupaten Tebo dan Kabupaten Merangin. Hal ini dibuktikan bahwa tingkat pengguliran kabupaten Tebo lebih baik dibandingkan Kabupaten Merangin.

Tabel 9. Hasil komparasi kelancaran pengguliran ternak

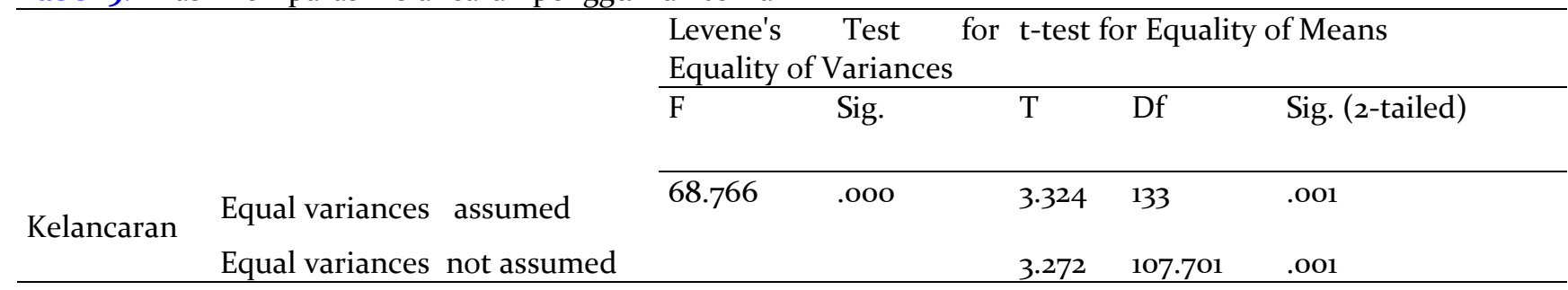

\subsubsection{Karakter}

Nilai sig. (2-tailed) sebesar 0,00o < 0,05, maka sesuai dasar pengambilan keputusan dalam Uji Independent Sampele T-Test, maka dapat disimpulkan bahwa terdapat perbedaan karakter antara Kabupaten Tebo dengan Kabupaten
Merangin. Hal ini dibuktikan dari karakter peternak yang meliputi tingkat kelancaran perguliran ternak, kepatuhan mengganti ternak mati/hilang dan kerelaan peternak terhadap resiko yang diterima. Perbedaan karakter peternak di Kabupaten Tebo dan Kabupaten Merangin terlihat pada Tabel 10. 
Tabel 1o. Hasil komparasi karakter peternak

\begin{tabular}{|c|c|c|c|c|c|c|}
\hline \multirow[b]{3}{*}{ Karakter } & & \multicolumn{5}{|c|}{$\begin{array}{l}\text { Levene's Test for } \\
\text { Equality of Variances }\end{array}$} \\
\hline & & $\mathrm{F}$ & Sig. & $\mathrm{T}$ & $\mathrm{df}$ & Sig. (2-tailed) \\
\hline & $\begin{array}{l}\text { Equal variances assumed } \\
\text { Equal variances not assumed }\end{array}$ & 70.136 & .000 & $\begin{array}{l}-4.723 \\
-4.587\end{array}$ & $\begin{array}{l}133 \\
78.470\end{array}$ & $\begin{array}{l}.000 \\
.000\end{array}$ \\
\hline
\end{tabular}

\subsubsection{Kapasitas}

Berdasarkan hasil pengujian menggunakan Spss, diketahui nilai nilai sig. (2-tailed) sebesar o,088 > 0,05, artinya kapasitas peternak yang dilihat dari system pemeliharaan dan pakan yang diberikan peternak antara Kabupaten Tebo dan Kabupaten Merangin dapat dikatakan sama. Perbedaan kapasitas peternak di Kabupaten Tebo dan Kabupaten Merangin dapat dilihat pada Tabel 11.

\subsubsection{Modal}

Berdasarkan hasil pengujian menggunakan Spss, diketahui nilai nilai sig. (2-tailed) sebesar 0,006 < 0,05, artinya modal peternak yang dilihat dari jumlah ternak yang dimiliki, biaya pembelian pakan konsentrat, biaya pembuatan kandang uang dikeluarkan serta biaya untuk pembelian perlengkapan alat-alat yang dikeluarkan antara Kabupaten Tebo dan Kabupaten Merangin dapat dikatakan berbeda. Perbedaan modal peternak di Kabupaten Tebo dan Kabupaten Merangin dapat dilihat pada Tabel 12.

Tabel 11. Hasil komparasi kapasitas peternak

Levene's Test for Equality t-test for Equality of Means

\begin{tabular}{lllll} 
of Variances & & & \\
\hline $\mathrm{F}$ & Sig. & $\mathrm{t}$ & $\mathrm{df}$ & Sig. (2-tailed)
\end{tabular}

Kapasitas

Equal variances assumed

$1.831 \quad .178$

$-1.716$

133

.088

Equal variances not assumed

$-1.701 \quad 121.620$

.091

Tabel 12. Hasil komparasi modal peternak

\begin{tabular}{lllll}
$\begin{array}{l}\text { Levene's } \\
\text { Equality of Variances }\end{array}$ & $\begin{array}{l}\text { Test } \\
\text { Eqrig. }\end{array}$ & T & & \\
\hline F & Sig.test for Equality of Means & & \\
& & & & \\
& & & & \\
\hline .201 & .654 & 2.814 & 133 & .006 \\
& & 2.805 & 129.815 & .006 \\
\hline
\end{tabular}

\section{Kesimpulan dan Saran}

\subsection{Kesimpulan}

Berdasarkan hasil penelitian dapat disimpulkan bahwa terdapat perbedaan karakter peternak dan modal yang dimiliki peternak pada pola gaduhan ternak sapi pemerintah daerah antara Kabupaten Tebo dengan Kabupaten Merangin, sedangkan pada kategori kapasitas peternak di Kabupaten Tebo dan Kabupaten Merangin dapat dikatakan sama. Dilihat dari tingkat kelancaran pengguliran ternak pada pola gaduhan ternak sapi di Kabupaten Tebo lebih baik dibandingkan dengan Kabupaten Merangin.

\subsection{Saran}

Saran yang dapat disampaikan adalah sebaiknya sebelum memberikan bantuan pemerintah melakukan seleksi calon peternak penerima bantuan ternak sapi terlebih dahulu, agar proses perguliran ternak pada pola gaduhan ternak sapi yang akan datang dapat berjalan lebih baik dan lancar.

\section{Referensi}

[1] Firmansyah, B. Rosadi dan Parizal, 2014. Kajian Pengembangan Ternak Sapi di Kabupaten Tanjung Jabung Timur. Laporan Penelitian. Kerjasama Dinas Peternakan Kabupaten 
Tanjung Jabung Timur dengan Fakultas Peternakan Universitas Jambi.

[2] Elly, F.H., Bonar. M, Sinaga, S.U. Kuntjoro, dan N. Kusnadi. 2008. Pengembangan Usaha Ternak Sapi Rakyat Melalui Integrasi SapiTanaman Di Sulawesi Utara. Jurnal Litbang Pertanian. 27(2), 2008. Hal : 63-68.

[3] Ibrahim, J. T., Sutawi dan Jayus, 2013. Analisis Kinerja Program Pengembangan Usaha Sapi Potong Pola Gaduhan Sistem Revolving (Studi di Distrik Bomberay Kabupaten Fakfak Provinsi Papua Barat). AGRISE Volume XIII No.2 Bulan Mei 2013.

[4] Hendri, J. 2009. Teknik Pengumpulan Data Primer. Riset Pemasaran - Universitas Gunadarma - 2009.

[5] Rahmatina, D. 2010. Prosedur Menggunakan Stratified Random Sampling Method Dalam Mengestimasi Parameter Populasi. JEMI. Vol. 1. No. 1, Desember 2010.

[6] Rosana, E.A., Saleh, dan Hadiyanto. 2010. Hambatan-hambatan Komunikasi yang Dirasakan Peternak dalam Pembinaan Budidaya Sapi Potong di Kabupaten Ogal Ilir. Jurnal Komunikasi Pembangunan Februari 2010. Vol. 08. No. 1. Hal : 27 - 41.

[7] Singarimbun, M. dan Effendy. 1995. Metode Penelitian Survei. $\mathrm{LP}_{3}$ ES, Jakarta.

[8] Marnidati, S. 2007. Motivasi dan pendapatan beternak kuda di kawasan wisata Pantai Parangtritis. Skripsi Fakultas Peternakan, Universitas Gadjah Mada, Yogyakarta.

[9] Wibowo, B dan Sumanto, 2013. Pola Budidaya Dan Gaduhan Usaha Sapi Potong di Kawasan Perkebunan Sawit Rakyat di Provinsi Lampung. Balai Penelitian Ternak, PO Box 221, Bogor 16002. 